\title{
Innovative Research on Teaching Management Mode of Colleges and Universities in China
}

\author{
Qing Zhang \\ Department of Economic Management, \\ North China Electric Power University, \\ Baoding, China
}

\begin{abstract}
In recent years, talent has become important resource to promote national development, and China will continue to expand enrollment in colleges and universities. However, under the new developing situation, shortcomings of the traditional teaching management mode of colleges and universities are constantly exposed, and the innovation is urgent and necessary. Firstly, the connotation and the present situation of teaching management mode of colleges and universities in our country are analyzed, and then the basic principles of innovation are determined. Finally, applicable innovation suggestions are put forward to provide reference for the reform of the teaching management in colleges and universities.
\end{abstract}

Keywords: colleges and universities; teaching management mode; innovation

\section{INTRODUCTION}

In recent years, the level of talents has gradually become the important factor that affects the development of the country, being focused by each country. Our country will continue to expand enrollment in colleges and universities and the number of students in colleges and universities is increasing, which makes the higher education develop in the direction of popularization ${ }^{[1]}$. Under the development situation of domestic and international education, shortcomings of the traditional teaching management mode of colleges and universities in our country are constantly exposed. In order to adapt to the current developing trend and improve the teaching quality of the higher education, it is high time to identify the problems and make innovation of the teaching management mode of colleges and universities in China. Literature [2] carried out detailed analysis of the existing teaching management modes, and then the modes were classified, compared and studied from three aspects of theory, territory and practice. Finally, the developing trend of the future was analyzed. Literature $[3,4]$ proposed that in order to improve the level of teaching management better, it was necessary to combine the scientific management thought with the humanism thought, which was beneficial to solve many teaching management problems under single value orientation. Literature [5] analyzed the system innovation of teaching management in colleges and universities from four aspects of curriculum system and structure, teaching management system, innovative activities and teaching monitoring system. Literature [6] advocated the combination of rigid constraints and flexible comprehensive service to realize reasonable and scientific teaching management in colleges and universities. Literature [7-10] analyzed the existing problems of teaching management mode in Chinese colleges and universities from different angles respectively, and put forward corresponding improving suggestions. The above researches provide a solid theoretical basis for making innovation of teaching management mode in colleges and universities, having important reference value for this paper.

Firstly, the connotation and status of teaching management mode of colleges and universities in China will be analyzed, and then the necessity and basic principles of innovating teaching management mode will be determined. Lastly, applicable suggestions for innovating teaching management mode of colleges and universities in China will be put forward to provide a reference for the reform of teaching management in colleges and universities.

\section{The connotation and present situation of teaching management mode of colleges and universities in China}

Many scholars have carried out a lot of researches on the teaching management mode of colleges and universities ${ }^{[11-}$

14]. Through referring to relevant literatures, the connotation of teaching management mode of colleges and universities is summarized as follows: under the direction of certain scientific management thought, it is a kind of directory and stable mode which can take effect on the practical operation of teaching activities, being formed in the process of teaching management activities to reflect the specific law of teaching management of colleges and universities. It includes the guiding ideology of scientific management, a set of reasonable teaching management procedures and method system as well as a series of teaching management strategies.

However, due to the combined effects of different external environment and internal factors, the teaching management mode of colleges and universities in China has been in a changing process of development, and just because of this dynamics, the teaching management mode of colleges and universities is facing the following status presently: 
(1) The administrative color of the teaching management mode in colleges and universities is strong. Whether it is from the content of management or the implementation of teaching plan, the teaching management mode in colleges and universities is always administrative. In terms of the content of management, the majority of colleges and universities execute the unified teaching content and teaching plan set by the state, usually lack of autonomy and initiative. Also, it greatly curbs the students' divergent and creative thinking, making them difficult to adapt to requirements of development of today's era. In terms of the implementation of teaching plan, it is often that teaching administrators manage teachers and teachers manage students, leading to the lack of exchange and communication between various levels. Moreover, the present teaching management mode usually means that the execution of teaching plan is just the implementation of the administrative instruction and this kind of teaching management mode is more passive.

(2) The teaching management mode of colleges and universities is lack of democracy. At present, most of teachers in colleges and universities are mainly engaged in teaching and scientific effort, and are less likely to participate in the school teaching management activities, such as the formulation of school policies or relevant plans. Even though teachers are given the corresponding rights, these works are often controlled by administrative personnel only. Usually, teachers rarely use these rights and administrative personnel will also limit their right, which has greatly affected teachers' enthusiasm and initiative of work and has a serious impact on teaching quality.

(3) The teaching effect evaluation system of teaching management in colleges and universities is imperfect. The teaching effect evaluation is used for evaluating and analyzing the teaching and teaching management effectiveness, which is an important way of university teachers and students participating in teaching management activities. However, the current evaluation is often concentrated in the assessment of teaching quality, paying little or no attention to the assessment of teaching management. Also, the evaluation effect is too formal and ineffective which needs to be solved urgently.

\section{Basic principles of innovation in teaching manage- ment mode of colleges and universities}

Along with the rapid development of market economy and globalization, the traditional teaching management mode of colleges and universities has not been able to satisfy the development of times and the popularity requirement of higher education. Nowadays, the teaching management mode should not only guarantee the smooth and orderly development of teaching management work, but also make the teaching management mode innovate and improve the teaching quality steadily. In addition, in recent years, the education reform in colleges and universities has promoted the innovation and improvement of teaching management mode to some extent. Innovative teaching management mode is not only an effective way for the development of colleges and universities, but also the requirements for improving the competitiveness of the talents, which is conducive to the cultivation of high quality and high level talents. Therefore, we must get a clear understanding of the developing requirements of times, and constantly adapt to the dynamic changes in the external environment, so as to realize the innovation and improvement of teaching management mode. Therefore, it is necessary to comply with the following two basic principles:

(1) People oriented and taking into account of science

The teaching management activity of colleges and universities is a special social work, whose fundamental purpose is to cultivate all kinds of talented person our country and society needs. The main body of the teaching management activity is person, and the subjective initiative of the person decides that teaching is not the simple teaching and learning. It is necessary to be people-oriented in teaching management activities of colleges and universities to take full use of people's enthusiasm. Meantime, scientific management system and restricted methods must be made to regulate the behavior of people. Therefore, it is essential for teaching administrators to fully mobilize the enthusiasm of teachers and students by using quantitative management methods and organizational system, making them take part in teaching management activities initiatively to improve the efficiency and level of teaching management.

(2) Respecting for individuality and service oriented

In teaching management activities of colleges and universities, on the one hand, college administrators should respect students' interests and give them enough space to fully display their individuality; on the other hand, they should respect the teachers' teaching style and allow them to teach students in accordance with their aptitude. The above two aspects are propitious to realize the all-round development of students and teachers ultimately. Moreover, as administrators of college teaching work, teaching administrators of colleges and universities should firstly convert position, change the past administrative practice and then set a direction for teaching management from the angle of serving teachers and students, making the teaching work of teachers and the learning process of students be carried out smoothly.

\section{Suggestions for the innovation of teaching manage- ment mode in colleges and universities}

Based on the present developing situation of teaching management mode of colleges and universities in China and the basic principles of innovating teaching management mode, this paper puts forward the following suggestions for the innovation of teaching management mode: 
(1) People oriented and enhancing teaching management awareness

In the system of modern education management theory, teachers and students are the main bodies of teaching management in colleges and universities. Therefore, under the innovative teaching management mode, we should follow the principle of "people oriented" and "respecting for individuality", and must fully mobilize the initiative of teachers and students, so that they could participate in the teaching management. On the one hand, teachers should be given political rights to achieve their high level of demands, and the innovative teaching management mode should let teachers participate in the formulation of school's major policy and research of school's developing direction. Also, it should make school affairs open, reflect teachers' wishes and strengthen the communication between administrators and teachers to maintenance teachers' rights. On the other hand, the innovative teaching management mode should transfer the traditional constraint-based teaching management system into the one reflecting students' individuality, so that students can understand the formulating reasons for school policy and system, which can develop students' identity and promote their independent engagement in study. Furthermore, students should be given the rights to choose curriculums and evaluate teachers.

(2) Scientific management and improving the innovating security system.

The innovation of teaching management mode in colleges and universities is inseparable from the restriction and influence of internal and external environment, especially the influence of organizational structure, system and idea of management and so on. It is necessary to strengthen the construction of the innovating security system. To innovate the teaching management mode, management idea is the foundation, and we should transfer passive management to active one; The perfection of management system is the guarantee, and according to characteristics of teaching and principles of scientific management, we should promote the normalized and detailed development of teaching management by using scientific management system; Reformation of organizational structure is the key, and we should flatten the existing organizational structure to make it adapt to teaching and scientific work; Informational technology is the support, which can improve the level of teaching management, and it is necessary to construct communication platform among administrators, teachers and students, so that it can timely feedback teaching quality and improve work efficiency.

(3) Service oriented and sound evaluating and monitoring mechanism

Teaching administrators in colleges and universities should follow the principle of "service oriented", and provide a good environment for teachers and students to meet their needs. At the same time, it is necessary to strengthen the evaluating and monitoring mechanism and make full use of information technology to make evaluation and su- pervision run through the whole term. For one thing, the innovative teaching management mode should include the comprehensive and objective evaluation of teaching administrators, and improve the rewards and punishments in the later stage of evaluation system. For the other thing, it is necessary to adopt various forms of surveillance and pay attention to mutual monitoring to ensure the orderly conduction of teaching work in colleges and universities.

\section{Conclusions}

The innovation of teaching management mode in colleges and universities is an important research topic in a new era. This paper analyzes the presently existing problems on the basis of the connotation of teaching management mode in colleges and universities, and then principles of the innovation of teaching management mode are explored. Finally, corresponding suggestions are put forward. However, the innovation of teaching management mode in colleges and universities is a long-term and arduous task, and it requires that teaching administrators continue to change their idea and explore constantly. Only by this can we gradually establish the teaching management mode of colleges and universities meeting the requirements of the new era.

\section{References}

[1] Yin Chunyan. Thinking about the Innovation of Teaching Management Mode of Colleges and Universities[J]. Journal of Chifeng University (Natural Science Edition), 2014,14:157-159.

[2] Zhang Lei. A Comparative Study on Teaching Management Modes in Higher Education Institution [D]. Hunan Normal University, 2007:10-42.

[3] Shen Xiaoping. Value Orientation of Transformation of Teaching Management Model Based in Chinese Universities and Colleges[J]. Journal of Liaoning Normal Universities (Social Science Edition), 2013,06:869-872.

[4] Qiu Longhu, Gu Meixi. The Precursor of the Integration of Science and Humanities - - George Sarton's Scientific Humanism[J]. Journal of Southeast University (Philosophy and Social Science), 2010,03:32-36.

[5] Zhu Huijuan, Han Zhaoxiang, Li Qiang. Research on the Innovation of Personnel Training and Teaching Management System in Colleges and Universities[J]. Journal of Examination Weekly, 2011,19:195-196.

[6] Wang Luyu. The Rationality of Teaching Management Idea of "Couple Hardness with Softness" in Colleges and Universities[J]. Heilongjiang Science and Technology Information, 2010,21:225.

[7] Lin Li. On the Innovation of Teaching Management Model for Newly Built Undergraduate Colleges[J]. Journal of Huaihai Institute of Technology (Humanities \& Social Science Edition), 2012, 10(15):97-99.

[8] Pan Hua, Pan Yaofang, Wang Lepeng. The Exploration of the Innovation of Basic Teaching Management Mode 
Based on "Triplicity" in Colleges and Universities[J]. Forum of Teaching and Education, 2013,30:15-16.

[9] Huang Liuying. The Transformation and Innovation of Teaching Management in Colleges and Universities under the New Situation[J]. Modern Communication, 2013,04:217.

[10] Cao Shuyuan. Improvement of Teaching Management Modes —-Based on the Contract Theory[D]. Liaoning Normal University, 2013:1-6.

[11] Gao Jinghong. Comparative Study on University Teaching Management Modes[J]. Journal of Northeast
Dianli University (Natural Science Edition), 2009,29(1):54-58.

[12] Niu Xizhen. Refinement: the Ideal Pursuit of Teaching Management in Colleges and Universities[J]. Journal of Southeast University (Philosophy and Social Science), 2009,06:119-122.

[13] Zhang Jundi. Discussion on Teaching Management Pattern and Development Trend of Ordinary University[J]. Journal of Hexi University. 2008,01:123-126.

[14] Yu Xiaoyun, Xia Weidong. Thinking of the Innovative Teaching Management Mode in Colleges and Universities under the New Situation [J]. Journal of Jinan Vocational College, 2007,05:28-29. 